\title{
Phytoplankton assemblages of the Southern Baikal in 1990-1995 and 2016-2018
}

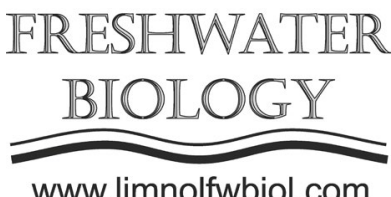

\begin{abstract}
Vorobyeva S.S.
Limnological Institute, Siberian Branch of the Russian Academy of Sciences, Ulan-Batorskaya Str., 3, Irkutsk, 664033, Russia

ABSTRACT. At present, the littoral zone of the Southern Baikal is under anthropogenic impact. The negative changes in underwater vegetation landscapes most dramatically appeared near the Listvyanka settlement. In this study, we compare phytoplankton assemblages from the surface layer (ca. $1.5 \mathrm{~m}$ depth) near the Listvyanka settlement collected during 1990-1995 and 2016-2018. We have compared phytoplankton data with solar irradiance and air temperatures. Phytoplankton community was represented by 70 taxa, where Bacillariophyta and Cryptophyta dominated the biomass. In 2016-2018, there were no significant differences in biomass or abnormal seasonal vegetation of the studied phytoplankton taxa compared to 1990-1995
\end{abstract}

Keywords: phytoplankton assemblage, species-dominant, Lake Baikal

\section{Introduction}

Over the past decade (Timoshkin et al., 2018), negative changes take place in the littoral zone of Lake Baikal. Dramatic examples of these changes are an expansion of green algae Spirogyra and a disease of Baikal sponge (Belikov et al., 2018; Khanaev et al., 2018; Timoshkin, 2018). On the other hand, there is no clear evidence of drastic changes in chemical and hydrological condition in this zone (Khodzher et al., 2017; 2018). In this study, we compared phytoplankton from the shallow zone of the Southern Baikal collected during 1990-1995 and 2016-2018. Unlike 2016-2018, the 1990-1995 period can be characterized by a low anthropogenic impact. In addition, a solar activity also differed in these periods. In this regard, this study was aimed at the investigation of phytoplankton diversity.

\section{Materials and Methods}

The studied area (ca. N51 52 ', E104 ${ }^{\circ} 9^{\prime}$ ) of Lake Baikal was near the settlement Listvyanka (head of the Angara River). Phytoplankton was sampled between January-December during 1990-1995 and 5-10 June and September during 2016-2018. The samples were collected with bathometer and net (using the Juday net with a $110 \mu \mathrm{m}$ mesh). The samples were fixed with the Utermöhl-solution and concentrated by sedimentation. The concentrate was placed into a $0.1 \mathrm{~mL}$ cell and examined under a Amplival (Carl Zeiss, Germany) microscope at two magnifications. At 800x magnification, net species and nanoplankton were identified, and at 2000x magnification - picoplankton. Phytoplankton was analyzed following the techniques from Starmach (1985), Round et al. (1990), Glezer et al. (1992). Cell counts were converted to algal biomass taking an average individual cell volume measured according to Makarova and Pichkily (1970) and Belykh et al. (2011).

\section{Results and Discussion}

\subsection{Phytoplankton assemblage in 1990-1995}

Phytoplankton assemblage comprised 70 taxa and their species. Amount of phytoplankton changed from 0.015 to 136 million cells $\mathrm{L}^{-1}$ with biomass of 0.004-2.13 $\mathrm{g} \mathrm{m}^{-3}$. Diatoms (20 taxa) were represented by Aulacoseira baicalensis, A. islandica, Cyclotella minuta, C. baicalensis, Nitzschia graciliformis, Synedra acus subsp. radians and Stephanodiscus meyeri. Gyrodinium helveticum, Gymnodinium baicalense, Peridinium baicalense and Glenodinium sp. dominated Dinophyta. Rhodomonas pusilla (up to 6064 thousand cells $\mathrm{L}^{-1}$ ) dominated Cryptophyta. Chrysophyta were formed by Chrysochromulina parva (up to 6439 thousand cells $\mathrm{L}^{-1}$ ) and Dinobryon cylindricum (up to 192 thousand cells $\mathrm{L}^{-1}$ ). Chlorophyta was represented by Monoraphidium contortum, M. arcuatum, Koliella longiseta and Chlamydomonas sp.

Diatoms and Cryptophyta in biomass were dominant in phytoplankton assemblage, 23.6 and $46.2 \%$, respectively (Fig. 1). In general, the bulk of Cyanophyta vegetation occurred during summer; however, the ratio of their biomass was almost $100 \%$ in January-Marth 1993 (Fig. 2). 


\subsection{Phytoplankton assemblage in 2016-2018}

Diatoms and Cryptophyta were also dominant, but their species composition changed compared to 1990-1996. Thus, the cell number of $A$. baicalensis, $N$. graciliformis and C. baicalensis was minor. For example, $N$. graciliformis reduced from 53-9490 thousand cells $\mathrm{L}^{-1}$ to 1.1 thousand cells $\mathrm{L}^{-1}$, and R. pusilla - from 6064 thousand cells $\mathrm{L}^{-1}$ to 669 thousand cells $\mathrm{L}^{-1}$. On the contrary, S. acus subsp. radians and Chlamydomonas sp. increased up to 46 and 72 thousand cells $\mathrm{L}^{-1}$. In general, species with small-sized cells dominated in 2016-2018.

\subsection{Correlation with climate parameters}

We have compared phytoplankton data with solar insolation and air temperatures. The first vegetation of Baikal phytoplankton occurs under ice in March-April (Bondarenko et al., 2012). The depth of snow cover on the ice also is important for plankton vegetation, since sunlight penetration depends on this parameter (Jewson et al., 2008). However, we did not find an increase in phytoplankton taxa during the ice periods. The studied periods were observed from maximum to minimum in the $22^{\text {nd }}$ solar cycle and declined in the $24^{\text {th }}$ cycle (Fig. 3). In addition, solar irradiance during 2016-2018 was lower than in 1996-1998. There is an obvious positive correlation between solar irradiance and ultraviolet index (Fig. 3). We assume that high phytoplankton vegetation most likely happens at high ultraviolet index. However, it was not observed in the maximum of the $22^{\text {nd }}$ cycle (1990-1992). Moreover, phytoplankton biomass was minimal during this period.

Despite the changes in the diatom plankton taxa, in 2016-2018 there were no significant differences in biomass or an abnormal seasonal vegetation of the studied phytoplankton taxa compared to 1990-1995. In this regard, we have not detected current negative changes in the phytoplankton community of the Southern Baikal.

\section{Conclusions}

We have compared phytoplankton taxa of the Southern Baikal collected in 2016-2018 with those of 1990-1995. Spring phytoplankton in 2016-2018 was characterised by an increase in Synedra acus subsp. radians and Dinobryon cylindricum, while large cells of A. baicalensis and $A$. islandica were minor. Diatoms and Cryptophyta were dominant in the biomass of phytoplankton assemblage during these periods. Increase in phytoplankton biomass was observed at low solar irradiance. In 2016-2018, there were no significant differences in biomass or an abnormal seasonal vegetation of the studied phytoplankton taxa compared to 1990-1995.

\section{Acknowledgements}

This study was supported by the basic funding within the projects Nos. 0345-2016-0006 (AAAA-A16116122110063-0), RFBR-17-29-05016

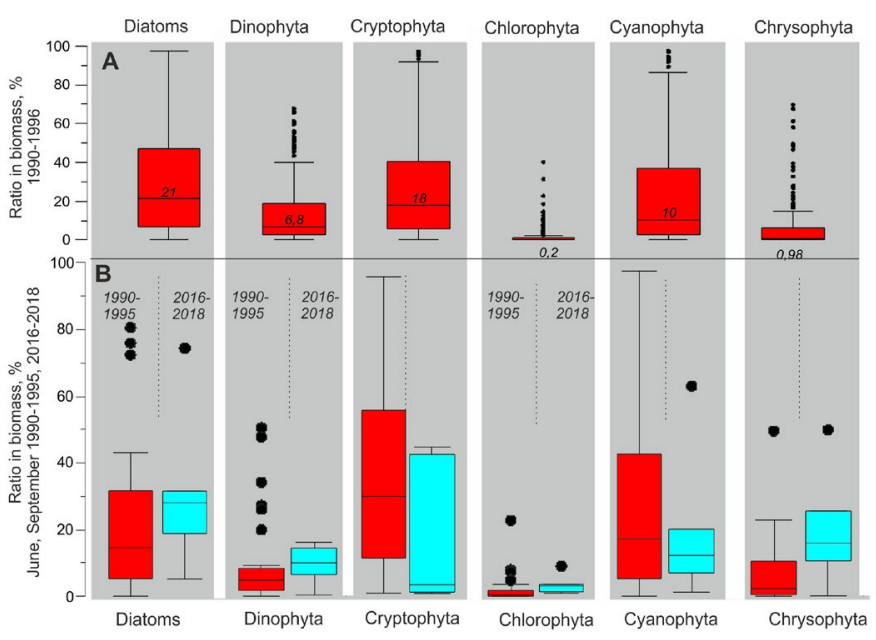

Fig. 1. Amount of phytoplankton taxa according to their biomass. The panel A (red) is the period of 1990-1995, the panel B -June and September of 1990-1995 (red) and 20162018 (bluish)

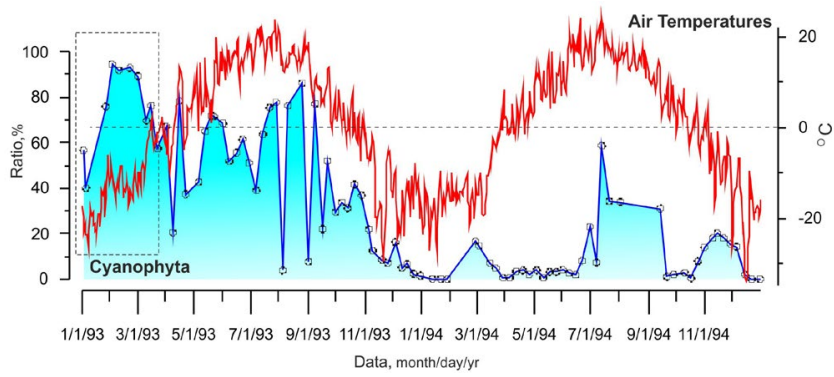

Fig. 2. Seasonal vegetation of Cyanophyta in comparison with air temperatures of 1993-1994
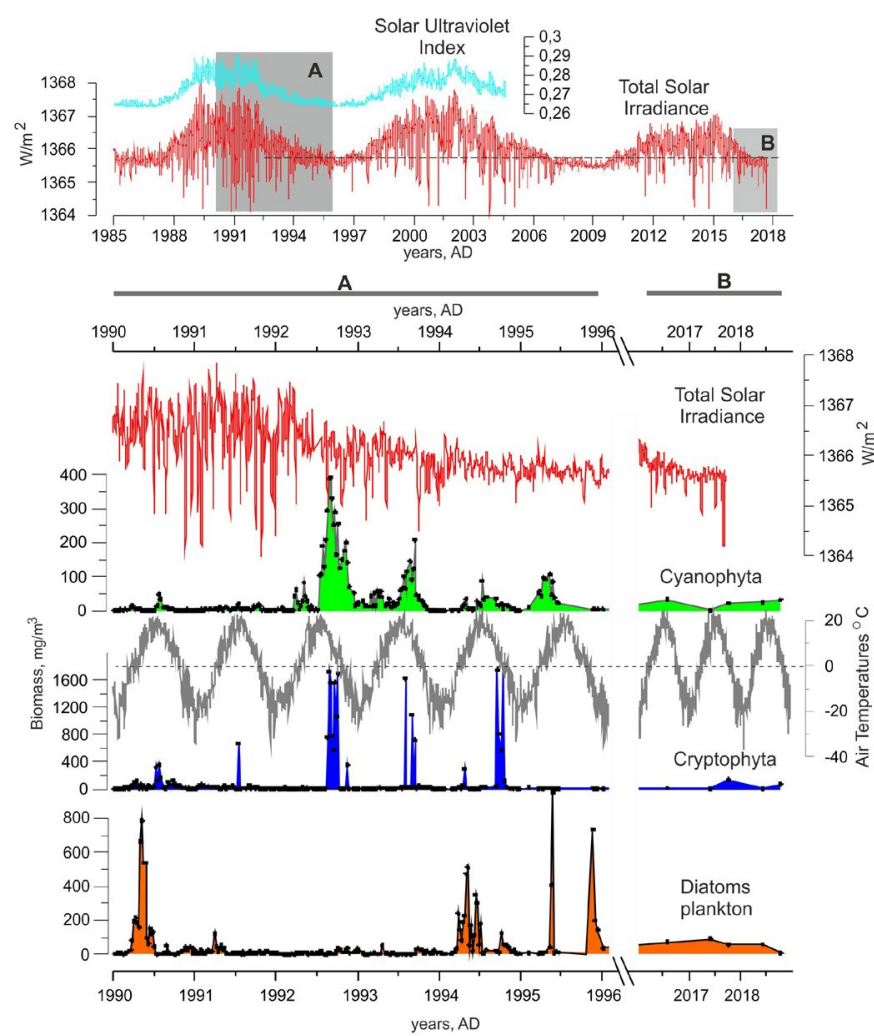

Fig. 3. Distribution of main phytoplankton taxa and changes in solar irradiance (Fröhlich, 2006), ultraviolet index (Viereck and Puga, 1999) and air temperatures during 1990-2018 


\section{References}

Belikov S.I., Feranchuk S.I., Butina T.V. et al. 2018. Mass disease and mortality of Baikal sponges. Limnology and Freshwater Biology 1: 36-42. DOI: 10.31951/2658-3518-2018-A-1-36

Belykh O.I., Bessudova A.Yu., Gladkikh A.S. et al. 2011. Guidelines for the determination of biomass of species of phytoplankton in pelagic zone in Lake Baikal. Irkutsk: Irkutsk University publisher. (In Russian)

Bondarenko N.A., Belykh O.I., Golobokova L.P. et al. 2012. Stratified distribution of nutrients and extremophile biota within freshwater ice covering the surface of Lake Baikal. The Journal of Microbiology 50: 8-16. DOI: 10.1007/ s12275-012-1251-1

Fröhlich C. 2006. Solar irradiance variability since 1978. Space Science Reviews 125: 53-65.

Jewson D.H., Granin N.G., Zhdanov A.A. et al. 2008. Resting stages and ecology of the planktonic diatom Aulacoseira skvortzowii in Lake Baikal. Limnology and Oceanography 53: 1125-1136.

Khanaev I.V., Kravtsova L.S., Maikova O.O. et al. 2018. Current state of the sponge fauna (Porifera: Lubomirskiidae) of Lake Baikal: Sponge disease and the problem of conservation of diversity. Journal of Great Lakes Research 44: 77-85. DOI: $10.1016 /$ j.jglr.2017.10.004

Khodzher T.V., Domysheva V.M., Sorokovikova L.M. et al. 2017. Current chemical composition of Lake Baikal water. Inland Waters 7: 250-258. DOI: 10.1080/20442041.2017.1329982
Khodzher T.V., Domysheva V.M., Sorokovikova L.M. et al. 2018. Hydrochemical studies in Lake Baikal: history and nowadays. Limnology and Freshwater Biology 1: 2-9. DOI: 10.31951/2658-3518-2018-A-1-2

Makarova I.V., Pichkily L.O. 1970. To some aspects of how to measure phytoplankton biomass. Botanical Journal 10: 1488-1494. (In Russian).

Round F.E., Crawford R.M., Mann D.G. 1990. The Diatoms. Biology and morphology of the genera. Cambrige: Cambrige University Press.

Starmach K. Chrysophyceae und Haptophyceae. 1985. In: Pascher A. (Ed.) Subwasserflora von Mitteleuropa. Bd. 1 Jena: VEB Gustav Fischer Verlag. (In German)

The diatoms of the USSR (fossil and recent). II (2). 1992. In: Glezer S.I., Makarova I.V., Moisseeva A.I., Nikolaev V.A. (Eds.). SPb: Nauka. (In Russian).

Timoshkin O.A. 2018. Coastal zone of the world's great lakes as a target field for interdisciplinary research and ecosystem monitoring: Lake Baikal (East Siberia). Limnology and Freshwater Biology 1: 81-97. DOI: 10.31951/2658-3518-2018-A-1-81

Timoshkin O.A., Moore M.V., Kulikova N.N. et al. 2018. Groundwater contamination by sewage causes benthic algal outbreaks in the littoral zone of Lake Baikal (East Siberia). Journal of Great Lakes Research 44: 230-244. DOI: 10.1016/j. jglr.2018.01.008

Viereck R., Puga L. C. 1999.The NOAA Mg I1 core-towing solar index: Construction of a 20-year time series of chromospheric variability from multiple satellites. Journal of Geophysical Research 104: 9995-10005. 